\title{
COVID-19 and the policy sciences: initial reactions and perspectives
}

\author{
Christopher M. Weible ${ }^{1} \cdot$ Daniel Nohrstedt ${ }^{2} \cdot$ Paul Cairney $^{3} \cdot$ David P. Carter $^{4}$. \\ Deserai A. Crow ${ }^{1} \cdot$ Anna P. Durnová $^{5} \cdot$ Tanya Heikkila $^{1} \cdot$ Karin Ingold $^{6,9}$. \\ Allan McConnell ${ }^{7}$. Diane Stone ${ }^{8}$
}

Published online: 18 April 2020

๑) Springer Science+Business Media, LLC, part of Springer Nature 2020

\begin{abstract}
The world is in the grip of a crisis that stands unprecedented in living memory. The COVID-19 pandemic is urgent, global in scale, and massive in impacts. Following Harold D. Lasswell's goal for the policy sciences to offer insights into unfolding phenomena, this commentary draws on the lessons of the policy sciences literature to understand the dynamics related to COVID-19. We explore the ways in which scientific and technical expertise, emotions, and narratives influence policy decisions and shape relationships among citizens, organizations, and governments. We discuss varied processes of adaptation and change, including learning, surges in policy responses, alterations in networks (locally and globally), implementing policies across transboundary issues, and assessing policy success and failure. We conclude by identifying understudied aspects of the policy sciences that deserve attention in the pandemic's aftermath.
\end{abstract}

Keywords Coronavirus $\cdot$ Pandemic $\cdot$ Policy sciences $\cdot$ Public policy $\cdot$ Policy processes · Crisis

Christopher M. Weible

chris.weible@ucdenver.edu

1 School of Public Affairs, University of Colorado Denver, 1380 Lawrence Street, Denver, CO 80238, USA

2 Department of Government, and Center of Natural Hazards and Disaster Science (CNDS), Uppsala University, Uppsala, Sweden

3 Division of History, Heritage, and Politics, University of Stirling, Stirling, UK

4 Program of Public Affairs, Department of Political Science, University of Utah, Salt Lake City, UT, USA

5 Institut für Höhere Studien - Institute for Advanced Studies, Vienna, Austria

6 Institute of Political Science and Oeschger Centre for Climate Change Research, University of Bern, Bern, Switzerland

7 Department of Government and International Relations, University of Sydney, Sydney, Australia

8 School of Public Policy, Central European University, Budapest, Hungary

9 Environnemental Social Science Department, Eawag, Dübendorf, Switzerland 


\section{Introduction}

The world is in the midst of the most severe pandemic in living memory. Scientists dubbed the pandemic's source "severe acute respiratory syndrome coronavirus 2" (SARS-CoV-2), but it is more commonly referred by the label assigned the disease it causes: coronavirus disease 2019 or "COVID-19". COVID-19 spread rapidly at a historic scale and with unprecedented impacts. Although milder symptoms include fever, aches, dry coughing, and shortness of breath, COVID-19 poses life-threatening conditions, ranging from respiratory failure to multiorgan disfunction. Older adults and those with pre-existing conditions (e.g., asthma) are at higher risk for the more severe impacts. However, everyone is susceptible, and anyone can contract and spread the disease.

The numbers of COVID-19 patients seeking medical care have strained entire healthcare systems worldwide. In many locations, outbreaks of COVID-19 have overwhelmed hospitals and healthcare professionals. Moreover, the effects go far beyond those felt by healthcare systems; they stretch across virtually every sector of society - from food systems to educationand have debilitated economies.

Societies rely on health sciences and medicine to forecast the pandemic's trajectory, to accelerate development of vaccines, to explain the situation to a worried public, and navigate the myriad of related health-related decisions. However, addressing the COVID-19 pandemic and its effects on society requires more than the actions of healthcare and medical professionals alone. It calls for engagement of citizens, governments at all levels, and a diverse array of organizations and individuals involved in policymaking processes and policy implementation.

Questions, thus, arise about the role of the policy sciences in comprehending such a crisis. Lasswell (1956a) envisioned the policy sciences as providing insights into such situations, challenging and informing ongoing processes and decisions, and foretelling of future scenarios, all with the intent of steering government and society toward greater human dignity for all. Since the formulation of this vision over seven decades ago, the policy sciences have evolved into a vibrant field of scholarship, marked by conceptual richness, theoretical diversity, and methodological pluralism (Cairney and Weible 2017; Torgerson 2017). This commentary capitalizes on the diversity and follows in the footsteps of Lasswell's vision by responding to the following question: What insights do the policy sciences offer to help us understand the COVID-19 pandemic?

We answer this question using ten policy perspectives that are featured in the policy sciences literature. These perspectives draw inspiration from Lasswell's (1956b) comprehensive portrayal of the functional elements that shape public policy. This requires going beyond analyzing any single aspect of public policy or a specific policy decision and understanding the dynamics of the processes, actors, and interactions that shape policy decisions in response to COVID-19. These include perspectives on policymaking (within country), crisis response and management, global policymaking and transnational administration, policy networks, implementation and administration, scientific and technical expertise, emotions, narratives and messaging, learning, and policy success and failure. 


\section{Policy perspectives}

\section{Policymaking (within country)}

The conventional conception of public policy casts it as encompassing both decisions and non-decisions of governments. As a reflection of societal values and priorities, public policies can take a "traditional" form, such as law, regulation, executive order, local ordinance, and court decision (among others). They can also take the form of on-the-ground regularized choices by frontline bureaucrats. In all these forms, public policies represent priorities of a society and they, in turn, shape society.

COVID-19 has spawned a surge in the number of public policies adopted, the forms in which they are adopted within and across governments, and with the range of their designs and contents. Most countries have closed or restricted their borders and restricted travel within borders. One-third of the world's population has been subjected to some social restrictions (from school closures to stay-at-home orders). These policy decisions exist across levels of government. For example, some occur at the national level, such as the world's largest lock down targeting India's 1.3 billion people, or at the subnational or local level, such as California's state-law to prohibit evicting tenants of commercial property. ${ }^{1}$ In examining this surge of policy change through the lens of the literature on policymaking, a few lessons emerge.

Governments adopt public policies through different pathways Supporting the literature on policy change (Weible and Sabatier 2017), the pathways to policy change during COVID-19 include: (1) learning, as demonstrated in the UK's shift from mitigation (partial closures) to suppression (strict lock downs) following projection of the infection and death consequences of the former (Walker et al. 2020; Hunter 2020); (2) negotiated agreement, as illustrated by the passing of stimulus packages around the world, including the USA (Werner et al. 2020), Canada (Bolongaro 2020), and Japan (Kyodo 2020); and (3) diffusing and transferring ideas across governments, with many drawing lessons from South Korea's widespread testing and China's strict quarantining. Policy decisions are further conditioned by contextual factors, including institutional (e.g., constitutional and legalistic structures) factors, cultural orientations, economies, and political styles (among others). For example, Sweden's response to COVID-19 has thus far avoided many of the lockdowns of other countries, a response that has been partially attributed to a culture of trust and responsibility. Finally, prompting all of these changes is the shock of COVID-19 itself, which directly affects healthcare systems worldwide, but indirectly affects other policy areas, for example, by postponing welfare reforms, environmental policies, and other actions deemed "non-essential". 2

Uncertainties exist regarding the duration and termination of policy decisions While we are experiencing a surge of policy change aimed at reducing immediate societal threats, there remains great uncertainty regarding which of these changes will remain permanent and which will be terminated. This includes questions about how they will be terminated (phased or immediate) and the political consequences of reversing decisions that increased welfare benefits to cope with the immediate crisis.

\footnotetext{
1 https://leginfo.legislature.ca.gov/faces/billTextClient.xhtml?bill_id=201720180SB939.

2 https://www.politico.eu/article/france-injects-billions-into-stimulus-plan-amid-coronavirus-chaos-bruno -le-maire-economic-catastrophe/; https://www.euractiv.com/section/energy-environment/news/green-dealfacing-delays-due-to-coronavirus-eu-admits/ Accessed: March 31, 2020.
} 
Government non-decisions become just as important as decisions Alongside the decision to take policy action is the choice to not act or delay action. These can be witnessed in information reporting delays, such as China not reporting human-to-human COVID-19 transmission (Madrigal and Meyer 2020), and deliberate value-based choices, as illustrated by President Trump's decision to rely on political pressure and markets over immediate activation of the Defense Production Act to produce and distribute needed medical supplies across the USA (Peres 2020).

\section{Crisis response and management}

Crisis management scholarship describes and explains societal actions in response to situations where there is a threat to core values, urgency to take action, and uncertainty concerning the situation and courses of action (Rosenthal et al. 1989). These conditions bring crucial leadership challenges associated with decision making, public information, sense making, accountability, learning, and reform (Boin et al. 2005) but also require broad collaboration and coordination involving multiple individuals and organizations. Crisis response and management shares an immediate interdependence with (1) public policies, including the content of previously and newly adopted public policies, (2) the interactions of individuals, groups, coalitions, and networks, and (3) contextual conditions, including income levels, local interactions, and global-level decisions.

Responses occur at strategic and operational levels Crisis response and management occurs at two levels (Boin and 't Hart 2010). The operational level refers to on-the-ground decisions and behaviors and includes medical personnel, epidemiologists, emergency managers, and other professionals coping with the pandemic's immediate threat. The strategic level includes political-administrative leaders that carry political responsibility and make strategic decisions, provide public accounts of events, and support coordination and collaboration. The ongoing need for adjustments in crisis response and management in the face of evolving circumstances and events require continuous engagement from both levels.

Mitigating value conflicts spark public controversies and blame-games During complex crises, multiple values are at stake simultaneously and decisions must be immediate. For the COVID-19 pandemic, one of the choices has been between mitigating versus suppressing COVID-19. Such choices impose different social and economic costs and benefits and raise important questions about how we value those costs and benefits. Given heightened public attention and policy impacts across society, most policy decisions (and non-decisions) are heavily scrutinized and politicized through framing contests and blame-games (Brändström and Kuipers 2003). Examples include debates around the Swedish strategy to ensure a slow spread of the virus (Henley 2020) and conflict in Brazil between state governors and the president over the best approach to tame the epidemic (Reuters 2020). Other governments, such as New Zealand (Roy 2020), Ireland (Power et al. 2020), and Iran (Karimi and Batrawy 2020), have been publicly criticized for doing too little too late. These experiences challenge the notion that policy conflicts can be temporarily suspended in times of crisis, with political opponents rallying around the proverbial flag until the worst is over. Indeed, there is a strong possibility that, while some policy conflicts will wane, others will wax as opportunities for political gain manifest and divisions emerge between those who support or oppose a government's response.

Transboundary crises can both spur and challenge collaboration Transboundary crises span functional areas and/or multiple jurisdictions over time, while posing novel governance challenges (Boin 2009; Bynander and Nohrstedt 2020). International collaboration 
flourished in response to COVID-19, channeled through the epistemic community of epidemiologists, virologists, and pharmacologists. Such collaboration is enabled by a global network of state agencies, private interests, and international institutions in efforts to coordinate public information activities and global research priorities (Mesfin 2020). In this transboundary crisis, countries exchange data and experiences to learn about the virus and its effects. High-level officials meet regularly to discuss travel bans, trade, and undertake joint actions to dampen economic impacts (Khan 2020). Meanwhile, many potential pitfalls plague the pursuit of such collaboration. Ample examples illustrate of how communication failures, political values and identities, and weak mandates can undermine efforts to achieve a collective crisis response (Boin and 't Hart 2010).

\section{Global policymaking and transnational administration}

Global policy processes refer to "a set of overlapping but disjointed processes of public-private deliberation and cooperation among both official state-based and international organizations and non-state individuals around establishing common norms and policy agenda for securing the delivery of global public goods or ameliorating transnational problems" (Stone and Ladi 2015, 2). Transnational administration is directly related and concerns "the regulation, management and implementation of global policies of a public nature by both private and public individuals operating beyond the boundaries and jurisdictions of the state, but often in areas beneath the global level" (Stone and Ladi 2015, 2). Self-evidently, the spread of COVID-19 presents a global policy problem but arguably has not (yet) become subject to transnational administration.

Inequalities drive differential impacts of policy responses, which, in turn, exacerbate inequalities Space for self-isolation is unaffordable in slums. Individuals have different possibilities to return home when business shut down, as illustrated by the situation in India, where thousands of migrant workers were stranded in wake of the lockdown (Abi-Habib and Yasir 2020). The pandemic also compounds inequalities between the so-called Global North and Global South, where "basic handwashing facilities are not available for $40 \%$ of the world population, let alone soap or hand sanitizers" (Racalossi de Moraes 2020).

Destabilization and reinforcement of global policy processes COVID-19 could lead to greater "de-globalization", a return of big government, and quite possibly more authoritarian government. Regional integration could be slowed, as seen in the European Union, where nation-states initially closed borders and prioritized national responses. However, the European Union also shows the continuation of collaboration in ensuring stability of inner markets and joint planning for the economic crisis. Similarly, while many efforts at international cooperation have been shaken, others are strengthened, including the ongoing exchange among experts of COVID-19 data (Varnum 2020). Public sector interventions, such as development projects and programs designed around global norms, could be at risk; this includes those expressed in the Sustainable Development Goals (SDGs). Additionally, traditional international organizations, such as the World Health Organization, have gained (or will gain) a legitimacy boost, alongside international bodies, including university centers for global health security, and events such as the World Health Summit.

Uncertainty about the locus of authority and influence of global professionals The policy communities that form around global health policy or the pandemic response include experts, bureaucrats, diplomats, consultants, and other professionals highly experienced in their policy sectors and international cooperation. However, the idea that public administration and decision making rests in the hands of professionals who work through 
international arrangements outside or beyond the accountability structures of established nation-state institutions is deeply disconcerting for those who believe such dynamics are anti-democratic and lead to unaccountable "global elites" (Stone 2019). Yet, overcoming COVID-19 rests with these professionals, illustrating the tension between effectiveness and accountability in transnational relations.

\section{Policy networks}

Swirling around all policy decisions and their implementation are policy networks (Marsh and Rhodes 1992; Jenkins-Smith et al. 2018), generally defined as entities seeking to influence policy, their relationships, and related outcomes. Policy networks include political parties, public agencies, elected offices, interest groups, non-government organizations, academia, think tanks, and many more. These entities relate to each other through a variety of ties important in policymaking, such as information and resource exchanges, collaboration, trust, and ally/enemy relations.

Policy networks react and contribute to the shifting of attention to policy issues and changing of government agendas The COVID-19 pandemic signifies a sudden and drastic shift in what issues policy networks pay attention to and, therefore, changes in agendas of many government decision-making venues, such as legislatures and parliaments. For example, Switzerland's parliament broke up its spring session and tabled other issues, such as climate change and pension reforms. By shifting foci on policy issues and changing agendas, there have also been changes in policy conflicts and in the relationships among people on different sides of policy issues. For example, policy networks in the context of COVID19 have focused more on the fundamental purpose of the policy issue area, whether that is to educate children or deliver food to grocery stores, and less on issues of secondary importance.

Prior policy networks condition policy and societal responses Many of the responses observed in COVID-19 reflect the vulnerabilities and strengths of prior policy networks, as well as emergent relationships (Bodin et al. 2019). For example, the stable and resilient policy networks that include national and subnational governments in Switzerland have been blamed for contributing to the country's slow pandemic response. However, Switzerland's slow response has also been attributed to its consensus-based and decentralized system of governance, which takes time to align top-down measures with growing awareness and fear among the people.

Changes in importance of policy networks' people and organizations, relations, and resources Once established, policy networks have been shown to be relatively stable (at least in organizational representation), with regularized patterns of interactions (JenkinsSmith et al. 2018). Some of these policy networks have been altered in the wake of the COVID-19 response. This includes making some relations superfluous and others essential, elevating the centrality of some entities (such as public authorities and experts), and pushing other entities to the periphery (such as political parties and associations). For example, in federalist countries, addressing the COVID-19 pandemic stresses the interplay between national and subnational authorities. In the USA, this is evident with New York Governor Cuomo's political rise in his ongoing tussles with President Trump over the gravity of New York's situation and the role (or lack thereof) of the federal government in supporting the state's mitigation efforts (Enton 2020). In Switzerland, some cantons have circumvented central decisions by taking stricter measures than those introduced by the national government. 


\section{Scientific and technical experts and information}

During periods of crisis and high uncertainty, the demand for scientific and technical expertise increases as governments and the public search for certainty in understanding problems and choosing responses. This creates a need for what is perceived as evidence-based policymaking, which signals to the public that decisions are being made based on reasoned and informed judgments that serve the public good, rather than special interests (Cairney 2016). Yet, scientific and technical experts also serve to inform, legitimize, and justify government responses to problems, even as political considerations and normative orientations continue to dominant such choices. The result is a simultaneous increased reliance on scientific and technical experts and politicization of scientific and technical information.

Scientific and technical experts become more central in policy responses to uncertain problems Before the pandemic emerged as a global crisis, a community of scientific and technical experts existed in areas including epidemiology, virology, public health, and medical sciences (Haas 1992). Without much public or political exposure, this community of experts has forged ahead in their advancement of public health knowledge in relation to pandemics. While these experts do not necessarily agree on all aspects of their expertise, they share foci, vocabularies, and methodological and theoretical orientations. The COVID-19 pandemic has suddenly elevated this community into the world's public and political spheres. Their vocabulary, for example, has entered the public lexicon, including words and concepts, such as "pandemic", "quarantine", "flattening the curve", "social distancing", "personal protective equipment" (PPE), and "coronavirus" (Shepherd 2020). These scientific and technical experts have become part of decision-making processes, as their names and images join political leaders as the face of how governments respond, notably illustrated by President Trump's shared press conferences with Anthony Fauci, director of the country's National Institute of Allergy and Infectious Diseases.

Governments invoke scientific and technical expertise to inform and legitimize problems, responses, and evaluations One of the fundamental purposes of scientific and technical information is to inform and legitimize governments' choices-especially in high-stake situations. The notion is that evidence is the basis for sound policy decisions. Scientific and technical experts become part of the rationale of governments' responses and serve as a means to reassure the public (Orange 2020). An increased demand for evidence-based policymaking also challenges experts (who need skills to simplify and communicate technical information) and policymakers (who need to balance political judgment and responsibility in the use of scientific and technical information).

Scientific and technical expertise can obscure accountability of decisions As scientific and technical experts help inform and legitimize decisions, they also obscure responsibility for policy responses and outcomes. Scientific and technical experts can help specify the severity of COVID-19 in a population, project its trajectories over time, and estimate the likely effects of different policy responses, from mitigation to suppression. Yet, formulating and adopting policy responses is the responsibility of government leaders. As scientific and technical experts become more prominent in the policy process, who is accountable for policymaking becomes more obscure.

\section{Emotions and public policy}

Policymakers rely on scientific and technical information to inform and legitimize their decisions. This reliance has contributed to an image of science as distinct from emotions, 
while emotions conjure images of spontaneity or irrationality. This image of emotions affects its role in policy processes, often placing it in what have been understood as the "emotional spheres of life", such as the home, intimate situations, and personal feelings (Stone 2013). Yet, emotions are part of the policy process and used strategically to shape public policy responses and effects on society (Durnová 2019).

Governments appeal to emotions to help legitimize policy responses and steer public reactions We see government officials referring to 'fear' of the rapid spread of COVID19 , as much as we observe emphases on 'trust' in fellow-citizens to comply with imposed policy measures. We see extensive references to "anxiety" regarding insufficient health resources to contain the pandemic, regarding social isolation, and regarding the general uncertainty about how long all this will last. Indeed, policymakers seem to have legitimized their policy choices through the emotional needs of the citizenry just as much as through perceptions of "objective" scientific evidence.

Emotionally charged language can recall cultural and historical contexts By referring to COVID-19 as the "invisible killer" that "threatens" the UK, Boris Johnson linked fear with the unprecedented and uncontrollable, legitimizing the drastic reduction in personal freedom in the country. ${ }^{3}$ Such portrayal is different from the words by Swedish Prime Minister Stefan Löfven, who described the virus as "testing our country, our society and us as human beings". ${ }^{4}$ In Löfven's discourse, "testing" gives an image of hope and the explicit reference to "human" invokes a compassionate response by society. While Johnson speaks about "each of us", he places this pronoun in the context of a "huge national effort", enabling him to urge "the people of this country to rise to that challenge and...to come through...stronger than ever...as many times in the past". Through the reference to the past, he appeals to emotions of patriotism and national pride. The latter helps interpret one of Donald Trump's framings of the pandemic as"foreign" and its spread as "cases entering our shores" (Kessler and Rizzo 2020). ${ }^{5}$ Trump strengthens this frame through the extensive use of military vocabulary, as when he described the virus is something to be "defeated". Iranian Prime minister Ali Khamenei uses a similar framing by claiming the virus "comes from the US" and could even be "manipulated" by them. This framing helps to legitimize the Iranian Government's limited ability to deal with the pandemic, as it links emotions of anxiety around COVID-19 to the anxiety around major geopolitical conflict. ${ }^{6}$

Policy responses force a reevaluation of the emotional spheres in societies Policy responses to the pandemic have rippled through societies, including into the homes and lives of citizens. National lockdowns, for example, have elevated the necessity of homeschooling, self-care in response to long isolation, and a need for psychological consultation

\footnotetext{
3 See Boris Johnson's address to the nation, March 23, 2020. https://www.theguardian.com/politics/ live/2020/mar/23/uk-coronavirus-live-news-latest-boris-johnson-minister-condemns-people-ignoring-twometre-distance-rule-in-parks-as-very-selfish. Accessed: March 31, 2020.

4 https://www.thelocal.se/20200322/in-english-prime-minister-stefan-lfvens-address-to-the-nation Accessed: March 31, 2020.

5 See Donald Trump's address to the nation, March 11, 2020:https://www.youtube.com/watch? $\mathrm{v}=\mathrm{mii6N}$ ydPiqI\#action=share Accessed: March 31, 2020.

6 https://en.radiofarda.com/a/coronavirus-chaos-in-iran-rouhani-wants-foreign-aid-hardliners-don-t/30508 842.html. Accessed: March 31, 2020.
} 
online services, such as those responding to the rise of home violence. ${ }^{7}$ These are examples of how policy responses to the pandemic have entered the emotional spheres of the global citizenry and pose novel challenges to short- and long-term government efforts (Jupp et al. 2016; Durnová and Hejzlarová 2018).

\section{Narratives and messaging}

The policy sciences focus attention on the messages and messengers that aim to influence decision-makers in government or the public (Crow and Jones 2018), which often include elements of emotions as described above. These messages can influence individual risk perceptions and risk reduction responses during a crisis like the COVID-19 pandemic. Understanding risks is key to persuading people and their governments to do something in the face of uncertainty and crisis. They need to know what the risk is, how bad it is, and what they need to do to reduce their risk or help the collective effort. Understanding these risks can be difficult for many and persuading people to change their behavior can be even more challenging - even with the best communications approach. Governments generally act with three points about narratives and messaging in mind during a crisis.

Governments attempt to provide sufficient information in a timely manner to the public China's initial response wherein the government failed to notify the public and global community about the nascent outbreak (Yuan 2020) falls at one end of the spectrum. At the other end of the spectrum, several US state governments hold daily briefings with media access and live coverage (Barnello 2020) - largely due to the failures of the federal government. In one early example, Ohio Governor Mike DeWine began holding daily briefings alongside his Heath Director before many other states. He was also the first US governor to bluntly warn about school closures: "So we've informed the superintendents, while we've closed schools for three weeks, that the odds are this is going to go on a lot longer and it would not surprise me at all if schools did not open again this year" (Anderson 2020).

Governments attempt to provide information that is accurate and non-contradictory to the public Just as important, there is a spectrum of observed government approaches to providing consistent and accurate information. For example, Taiwan's, Singapore's, and South Korea's governments acted swiftly to provide residents information and testing (Apuzzo and Gebrekidan 2020). In contrast, the US government has provided haphazard and contradictory information (Lopez 2020), affecting the public's trust and reactions (Sanders 2020). President Trump has contradicted his own public health experts numerous times, sowing confusion about the virus's severity and characteristics (Abadi et al. 2020). On the other hand, many US governors-including New York, Ohio, Colorado, and California-have been praised for their consistent approach to providing information about the outbreak in their states.

Governments can spawn controversies by engaging in speculations Governments can create confusion and conflict through speculation and dissemination of false information. For example, President Trump lauded the potential of the drug chloroquine to counter the novel coronavirus. As reported in $\mathrm{CNN}$, "Health officials in Nigeria have issued a warning over chloroquine after they said three people in the country overdosed on the drug, in

\footnotetext{
7 See for example, https://www.euronews.com/2020/03/28/domestic-violence-cases-jump-30-during-lockd own-in-france. Accessed: March 31, 2020.
} 
the wake of President Trump's comments about using it to treat coronavirus" (Busari and Adebayo 2020).

\section{Learning}

Various strands of research in the policy sciences have recognized that learning plays a critical role in our ability to understand, influence, and address complex policy issues. Learning can bring new issues to light, challenge previously held beliefs, and help identify innovative policy responses. In democracies, processes that facilitate learning, such as stakeholder dialogue, are often valued for the potential to bring diverse forms of knowledge-whether scientific, experiential, or value-based-into policy decision making. Given the importance of learning, and the challenges associated with it, numerous scholars have sought to diagnose learning in policy contexts (Heikkila and Gerlak 2013; Moyson et al. 2017), including learning around crises (Crow et al. 2018).

Urgency triggers learning from others' experiences The pandemic illustrates intra-crisis learning, including how experts and decision-makers continuously review and update policy responses as new knowledge becomes available (Moynihan 2008). The time lag between countries' experience with COVID-19-particularly in societies that were affected early, including China and Italy-provides other countries an opportunity to monitor the pandemic and evaluate policy responses, as a basis for their own responses. We also see evidence of learning in a variety of domains and scales of policymaking: from local leaders who learn from public health agencies on the extent and impact of the virus in their communities, to parents learning from each other how to co-produce their children's education from schools (Darling-Hammond 2020).

Learning manifests in different ways Learning can take various forms: as updates to our understanding of instrumental or technical aspects of a policy problem, as changes to our underlying policy beliefs or values about societal priorities in responding to problems, and as fundamental alterations to the institutions that target these problems. Instrumental learning around COVID-19, for instance, has occurred regarding how long the virus can linger on surfaces, leading to closures of many public and private buildings. Influencing our value orientations, the COVID-19 crisis has brought attention to underlying social dilemmas that make people either more vulnerable to the virus, or vulnerable to the efforts to stop it. We also see evidence of learning about the strength and vulnerabilities of the institutional rules structuring our governments and their efforts to tame the pandemic. Sweden, for example, passed a new bill to empower the national government to close temporarily schools in the nation, which was previously a municipality-level responsibility. ${ }^{8}$

Different barriers inhibit learning In the case of the COVID-19 pandemic, learning is potentially constrained by several issues: the immediacy and urgency of the crisis, popular demands for forceful action, limitations in technical knowledge, and politicization (Stern 1997). This raises questions as to whether we are learning the right things and whether the right people are learning. Many of our policy choices reflect a "muscle memory" from the past to guide us through the crisis until we can pause and reflect, allowing for deeper forms of learning. With COVID-19, we have some experiences to draw on, as illustrated in the USA ensuring oversight in the relief bill, building in part from perceptions of what the

\footnotetext{
8 https://www.riksdagen.se/en/news/2020/mar/19/new-law-will-give-the-government-and-school-gover ning-bodies-extended-powers-regarding-school-activities/. Accessed: March 31, 2020.
} 
2008 stimulus package lacked (Woodruff 2020). However, the novelty of COVID-19 may also prevent learning opportunities from the past to guide us (Brändström et al. 2004). At the same time, in the face of a crisis we may be even more inclined to look to those who are most like us, politically and ideologically, for lessons. For instance, across subnational governments in the USA we have seen differing approaches to lockdown policies that correspond closely with political ideologies (Adolph et al. 2020).

\section{Implementation and administration}

Public policy is not self-enacting; rather, administrative actions bridge a government's intent to do something (policy) and the real-world impacts of that intent. Crises such as the COVID-19 pandemic demand swift and coordinated action that adapts fluidly to conditions- "contingent coordination" in the words of Kettl (2003). Such coordination generally spans different agencies and across levels of government. Furthermore, as devolution and privatization of public services have shifted critical administrative functions to disparate entities both within and outside of government, policy responses to even simple emergencies call for joint action between government organizations, nonprofits, for-profit enterprises, and individuals. Every aspect of implementation shapes how public policy takes place "on the ground"-from how administrators interpret policy directives to the way front-line personnel operationalize them.

Administrative fragmentation and decentralization complicate implementation Pandemic response requires interagency collaboration across fragmented bureaucratic structures and distinctive organizational cultures. In the USA, for example, the Federal Emergency Management Agency (FEMA) needs access to critical Health and Human Services (HHS) information, while directing agencies such as the Army Corps of Engineers to set up emergency medical infrastructure and the Department of Transportation to maintain supply chains. Meanwhile, administrators in state, local, and tribal governments look to agencies such as HHS and FEMA for direction and assistance. Although the goal is streamlined hierarchical coordination, power struggles between levels of government are just as likely (Lester and Krejci 2007).

Administrators face additional challenges in coordinating with nonprofit and for-profit partners. Absent formal mechanisms of control, they must leverage indirect measures. For example, administrators have devised credible commitments with for-profit and nonprofit hospitals to encourage them to forgo elective surgery revenues (by canceling procedures), which creates additional capacity for treatment of COVID-19 patients. Governments' reliance on nonprofits to not only deliver essential public services, but also subsidize government funding of them, is on full display in the midst of the crisis. Nonprofits are seeing unprecedented demand for their services while facing the financial implications of the pandemic's impact on the economy. As described by Goodwill CEO Steven Preston (as cited in Associated Press 2020): "The financial impact of the crisis has put the very survival of many essential service providers at risk...[nonprofits] are our society's shock absorber when crisis hits".

Front-line workers exercise discretion and self-regulation Front-line personnel rely on discretion to develop routines, norms, and creative strategies as a means of coping with the often unreasonable responsibilities assigned to them (Hupe 2013). Heuristics and workarounds are particularly relevant in the pandemic. Examples include tragic accounts of the revised triage frameworks physicians apply to manage staggering infected patient numbers 
and the solutions that hospital staff devise to address shortages of critical medical equipment, from facemasks to ventilators.

Co-production requires overcoming collective action challenges The pandemic calls on citizen co-production (Voorberg et al. 2015) in the realization of policy goals on an unprecedented scale. "Social distancing" recommendations and "stay-at-home" orders ask residents to put aside their self-interests-from the comfort of group interactions to the critical desire for financial security - to reduce the virus' spread and "flatten the curve". Because many such policies are voluntary, levers for encouraging compliance with them oblige public servants to find ways to activate residents' civic sense of duty to comply and social pressures. Such efforts are likely to be more effective if they harness the popular legitimacy held by intermediaries, from civic organizations to for-profit companies, to exert normative pressures toward compliance.

\section{Policy success and failure}

Policy sciences are often used to understand policy evaluation in more normal rhythms of policy cycles, strong evidence bases, and evaluative tools/techniques. However, COVID-19 has propelled it out of these normal rhythms by imposing extreme urgency, ambiguity, and value conflicts. Insights from the literature on policy success and failure-with its extension to the crisis management domain (McConnell 2011)—provide a useful starting-point for assessing policy making under such extreme conditions.

Who is affected and to what extent influence frames of success or failure Policy decisions are likely to benefit some populations and harm others. Banning international flights into a country may be successful for the health of a national community, but not from the vantage point of families stranded overseas who cannot return. There is also ambiguity when it comes to the extent of success or failure, such as assessing the proportion of a population being tested, being infected, recovering, and dying. Challenges surmount when data supporting these assessments are absent and are considered at different times.

Success or failure judged as part of decisions, processes, and politics Crisis decisions focus on public policy and can be evaluated based on containing threats, minimizing damage, and restoring order and stability. Crisis processes can be evaluated against the criteria for adherence to processes relevant to resolving the crisis at hand (from activating plans to well-judged improvisation), to following a process that is legitimate, through following constitutional conventions or garnering legitimacy from key stakeholders. Crisis politics focus on success from the perspective of governments and can be assessed against reputational protection, enhancement, and popular support; ability to manage policy and political agendas with as little backfire as possible; and capacity to maintain long-term governance/ ideological visions.

This threefold distinction helps capture many of the dynamics and tensions of how we assess responses to the COVID-19 pandemic. For example, a government may fail through initial reluctance to act on early warning signs about the potential risks of the virus (decision failure), but succeed much more in garnering political sympathies and support (political success) for its struggle in the face of adversity. A government may succeed in rushing through a series of draconian measures such as quarantine and lockdowns (process success) but face a backlash against the centralization of political power (political failure).

It is possible to conceive of a spectrum from success to failure We may judge outcomes leaning toward the success end of the spectrum even when there have been shortfalls, such as when initial delays in ordering testing kits still lead to perceived success overall once 
testing kits arrive and high-volume laboratory processing occurs. Correspondingly, outcomes may also be judged as leaning toward failure, despite small gains and comforts, such as Italy's collapsing emergency healthcare, despite some lives being saved. In the middle of this spectrum is a mix of successes and failures, akin to a tug-of-war over perceptions of the outcomes related to crisis decisions, processes, and politics.

Lenses and narratives shape perceptions of success and failure We will always view success and failure through lenses of values and other orientations (Lasswell 1970). If we feel the overriding priority for providing financial aid to the unemployed and low-waged, then we are unlikely to view bailouts for airlines as success. Adapting Bovens and 't Hart (1998) useful approach to COVID-19 is the assessment of the extent of success/failure, its causes (from mismanagement to inevitability) and implications for future crisis decisions (from refining existing directions to the need for dramatic change). This can be applied to the "whole of government" response or simply to one aspect of the responses. Multiple narratives and variations are possible, but we outline three hypothetical illustrations:

- First is the success trajectory e.g., a reduction in the number of daily cases is the product of the early banning of international flights from China. Our successes were and will continue to be the result of pre-emptive action.

- Second is the failure trajectory e.g., the current exponential rise in confirmed cases is the product of complacent political leadership, more interested in calming fears for the next election than in addressing very real threats. New thinking is needed to avert more unnecessary tests.

- Third is the mixed trajectory e.g., the government has succeeded in slowing down the rate of new infections but hospitals still cannot cope. We cannot afford to be complacent and must channel additional funds into front-line healthcare.

\section{Conclusion}

Lasswell (1956a) envisioned the policy sciences to be both relevant and timely. In this spirit, this commentary draws immediate reflections based on different perspectives of the policy sciences to understand the COVID-19 pandemic. The pandemic poses unprecedented challenges in its immediate need for action, global span, and magnitude of impacts. We write this at a time when the pandemic has not yet reached its peak; hence, we draw on early observations in a concerted effort to offer insights into the ways in which scientific and technical expertise, emotions, and narratives and messaging legitimize policy decisions and shape relationships among citizens, organizations, and governments. We demonstrate the varied processes of adaptation and change, including learning, surges in policy responses, shifts in networks locally and globally, implementing and administering policies in response to transboundary issues, and assessing policy success and failure.

There are also understudied aspects of the policy sciences that deserve more attention in the aftermath of the COVID-19 pandemic. These include (but are not limited to) the following avenues of research:

- The global response to the pandemic has heightened the need for renewed research not only on the surge of new policy decisions, but also on the effects of non-decisions and policy terminations. 
- Given the necessity for mass behavioral change to overcoming the pandemic, more research is needed to examine the relationship between crises and public responses.

- The pandemic has further exposed economic and political inequalities in global policy responses, yet questions remain about how to mitigate these inequalities to support the world's most vulnerable.

- The political response to the pandemic has altered priorities and, thus, the focus and intensities of policy conflicts, but the characteristics and permanency of these changes remain unknown.

- The increased reliance on scientific and technical expertise in making policy decisions raises questions about political accountability in policymaking.

- While much of our focus has been on the use of scientific and technical expertise in supporting policy decisions, we have not focused enough on the role of emotions and their effects on legitimizing decisions and achieving desirable outcomes.

- Even though narratives and messaging are important, we still know little about how to construct and deliver them effectively to influence public behavior.

- The pandemic has renewed attention to the importance of, and how little we know about, learning under stress and urgency in the middle of a crisis.

- Given the necessity of linking mass responses and policy decisions, the pandemic reinforces the need to foster understanding in both public policy co-creation and co-production.

- While we know base values and other orientations drive policy success and failure, questions remain about how to deal with the tradeoffs between them.

This commentary also shows that the strength of the policy sciences lies in its capacity to provide general insights related to interactions between public policy and society. Of course, given breadth and depth found in the policy sciences, we make no claims that this commentary comprehensively draws from all its sources and relevant perspectives. We leave it to others to continue the conversation that we know will shape much of our research in the years to come.

\section{References}

Abi-Habib, M., \& Yasir, S. (2020, March 29, 2020). India's coronavirus lockdown leaves vast numbers stranded and hungry. New York Times. https://www.nytimes.com/2020/03/29/world/asia/coronaviru s-india-migrants.html. Retrieved March 31, 2020.

Abadi, M., Baylon, J., \& Lindsay, R. (2020, February 26, 2020). 6 times Trump contradicted public officials about the coronavirus pandemic. Business Insider. https://www.businessinsider.com/trump-coronaviru s-contradicting-public-health-officials-2020-3. Retrieved March 31, 2020.

Adolph, C., Amano, K., Bang-Jensen, B., Fullman, N., \& Wilkerson, J. (2020). Timing state-level social distancing responses to COVID-19. https://github.com/COVID19StatePolicy/SocialDistancing. Retrieved March 31, 2020.

Anderson, N. (2020, March 15, 2020). Gov. DeWine: 'I wouldn't be surprised if schools didn't reopen this school year'. Fox8. https://fox8.com/news/coronavirus/gov-dewine-i-wouldnt-be-surprised-if-schoolsdidnt-reopen-this-school-year/. Retrieved March 31, 2020.

Apuzzo, M., \& Gebrekidan, S. (2020, March 20, 2020). Can't get tested? Maybe You're in the wrong country. New York Times. Retrieved from https://www.nytimes.com/2020/03/20/world/europe/coronaviru s-testing-world-countries-cities-states.html. Retrieved March 31, 2020.

Associated Press. (2020, March 21, 2020). Virus outbreak poses massive challenges for US charities. The New York Times. https://www.nytimes.com/aponline/2020/03/21/business/bc-virus-outbreak-embat tled-charities.html. Retrieved March 31, 2020. 
Barnello, J. (2020, March 25, 2020). More than 30,000 coronavirus cases in NY; Cuomo says peak could come in 3 weeks. https://cnycentral.com/news/local/watch-gov-cuomo-holds-daily-covid-19-briefingfrom-albany-03-25-2020. Retrieved March 31, 2020.

Bodin, Ö., Nohrstedt, D., Baird, J., Summers, R., \& Plummer, R. (2019). Working at the "speed of trust": pre-existing and emerging social ties in wildfire responder networks in Sweden and Canada. Regional Environmental Change, 19, 2353-2364.

Bolongaro, I. (2020, March 25, 2020). Trudeau wins opposition backing for $\$ 57$ billion virus aid package. https://www.bloomberg.com/news/articles/2020-03-25/trudeau-wins-opposition-backing-for-57-billi on-canada-package. Retrieved March 31, 2020.

Boin, A., 't Hart, P., Stern, E., \& Sundelius, B. (2005). The politics of crisis management: Public leadership under pressure. New York: Cambridge University Press.

Boin, A. (2009). The new world of crises and crisis management: Implications for policymaking and research. Review of Policy research, 26(4), 367-377.

Boin, A., \& 't Hart, P. (2010). Organising for effective emergency management: Lessons from research. Australian Journal of Public Administration, 69(4), 357-371.

Bovens, M., \& 't Hart, P. T. (1998). Understanding policy fiascoes. Piscataway: Transaction Publishers.

Brändström, A., Bynander, F., \& 't Hart, P. T. (2004). Governing by looking back: Historical analogies and crisis management. Public Administration, 82(1), 191-210.

Brändström, A., \& Kuipers, S. (2003). From 'normal incidents' to political crises: Understanding the selective politicization of policy failures 1. Government and opposition, 38(3), 279-305.

Busari, S., \& Adebayo, B. (2020, March 23, 2020). Nigeria records chloroquine poisoning after Trump endorses it for coronavirus treatment. CNN. https://www.cnn.com/2020/03/23/africa/chloroquin e-trump-nigeria-intl/index.html. Retrieved March 31, 2020.

Bynander, F., \& Nohrstedt, D. (Eds.). (2020). Collaborative crisis management: Interorganizational approaches to extreme events. New York: Routledge.

Cairney, P. (2016). The politics of evidence based policymaking. London: Palgrave.

Cairney, P., \& Weible, C. M. (2017). The new policy sciences: Combining the cognitive science of choice, multiple theories of context, and basic and applied analysis. Policy Sciences, 50(4), 619-627.

Crow, D., \& Jones, M. (2018). Narratives as tools for influencing policy change. Policy \& Politics, 46(2), 217-234.

Crow, D. A., Albright, E. A., Ely, T., Koebele, E., \& Lawhon, L. (2018). Do disasters lead to learning? Financial policy change in local government. Review of Policy Research, 35(4), 564-589.

Darling-Hammond, L. (2020, March 19, 2020) Learning in the Time of COVID-19. Forbes. https://www. forbes.com/sites/lindadarlinghammond/2020/03/19/learning-in-the-time-of-covid-19/\#7693e8967203. Retrieved March 31, 2020.

Durnová, A. P., \& Hejzlarová, E. M. (2018). Framing policy designs through contradictory emotions: The case of Czech single mothers. Public Policy and Administration, 33(4), 409-427.

Durnová, A. P. (2019). Understanding emotions in post-factual politics: Negotiating truth. Cheltenham: Edward Elgar Publishing.

Enton, H. (2020, March 29, 2020). The surprising rise of Andrew Cuomo. CNN. https://www.cnn. com/2020/03/28/politics/andrew-cuomo-polls/index.html. Retrieved March 31, 2020.

Haas, P. M. (1992). Banning chlorofluorocarbons: Epistemic community efforts to protect stratospheric ozone. International organization, 46(1), 187-224.

Heikkila, T., \& Gerlak, A. K. (2013). Building a conceptual approach to collective learning: Lessons for public policy scholars. Policy Studies Journal, 41(3), 484-512.

Henley, J. (2020, March 23, 2020). Swedish PM warned over 'Russion roulette-style' Covid-19 strategy. The Guardian.https://www.theguardian.com/world/2020/mar/23/swedish-pm-warned-russian-roulettecovid-19-strategy-herd-immunity. Retrieved March 31, 2020.

Hunter, D. J. (2020). Covid-19 and the stiff upper lip-The pandemic response in the United Kingdom. New England Journal of Medicine. Retrieved March 31, 2020.

Hupe, P. (2013). Dimensions of discretion: Specifying the object of street-level bureaucracy research. der moderne staat-dms. Zeitschrift für Public Policy, Recht und Management, 6(2), 425-440.

Jenkins-Smith, H. C., Nohrstedt, D., Weible, C. M., \& Ingold, K. (2018). The advocacy coalition framework: An overview of the research program. In C. M. Weible, \& P. A. Sabatier (Eds.), Theories of the policy process (pp. 135-171). Abingdon: Routledge.

Kessler, G. \& Rizzo, S. (2020, March 12, 2020). Fact-checking Trump's address to the nation on the coronavirus. The Washington Post.https://www.washingtonpost.com/politics/2020/03/12/fact-checking-trump s-address-nation-cornavirus/. Retrieved March 31, 2020.

Jupp, E., Pykett, J., \& Smith, F. M. (Eds.). (2016). Emotional states: Sites and spaces of affective governance. Milton Park: Taylor \& Francis. 
Khan, M. (2020, March 17, 2020). The EU fights the coronavirus on all fronts. Financial Times. https:// www.ft.com/content/2e49bbc4-67dc-11ea-a3c9-1fe6fedcca75. Retrieved March 31, 2020.

Karimi, N., \& Batrawy A. (2020, March 18, 2020). Iran's president rejects criticism of coronavirus response. AP. https://apnews.com/73378b9cdecef66ec5ae74af1ec52c63. Retrieved March 31, 2020.

Kettl, D. F. (2003). Contingent coordination: Practical and theoretical puzzles for homeland security. The American Review of Public Administration, 33(3), 253-277.

Kyodo, J. (2020, March 14, 2020). Japan may dish out cash to households impacted by coronavirus. The Japan Times. https://www.japantimes.co.jp/news/2020/03/26/business/economy-business/cash-benef its-coronavirus/\#.XoTNiohKg2w. Retrieved March 31, 2020.

Lasswell, H. D. (1956a). The political science of science: An inquiry into the possible reconciliation of mastery and freedom. American Political Science Review, 50(4), 961-979.

Lasswell, H. D. (1956b). The decision process: Seven categories of functional analysis. Maryland: Bureau of Governmental Research, College of Business and Public Administration, University of Maryland.

Lasswell, H. D. (1970). The emerging conception of the policy sciences. Policy sciences, 1(1), 3-14.

Lester, W., \& Krejci, D. (2007). Business "not" as usual: The national incident management system, federalism, and leadership. Public Administration Review, 67, 84-93.

Lopez, G. (2020, March 20, 2020). Trump's expert urged caution about a coronavirus treatment. Trump hyped it up anyway. Vox. https://www.vox.com/policy-and-politics/2020/3/20/21188397/coronaviru s-trump-press-briefing-covid-19-anthony-fauci. Retrieved March 31, 2020.

Madrigal, A. C., \& Meyer, R. (2020, March 21, 2020). How the coronavirus became an American catastrophe. The Atlantic. https://www.theatlantic.com/health/archive/2020/03/how-many-americans-are-sicklost-february/608521/. Retrieved March 31, 2020.

Marsh, D., \& Rhodes, R. A. W. (1992). Policy networks in British government. Oxford: Clarendon Press.

McConnell, A. (2011). Success? Failure? Something in-between? A framework for evaluating crisis management. Policy \& society., 32(2), 63-76.

Mesfin, M. (2020, March 21, 2020). It takes a world to end a pandemic. Foreign Affairs. https://www.forei gnaffairs.com/articles/2020-03-21/it-takes-world-end-pandemic. Retrieved March 31, 2020.

Moynihan, D. P. (2008). The dynamics of performance management: Constructing information and reform. Washington, DC: Georgetown University Press.

Moyson, S., Scholten, P., \& Weible, C. M. (2017). Policy learning and policy change: Theorizing their relations from different perspectives. Policy and society, 36(2), 161-177.

Orange, R. (2020, March 28, 2020). As the rest of Europe lives under lockdown, Sweden keeps calm and carries on. The Guardian. https://www.theguardian.com/world/2020/mar/28/as-the-rest-of-europ e-lives-under-lockdown-sweden-keeps-calm-and-carries-on. Retrieved March 31, 2020.

Peres, M. (2020, March 26, 2020). President Trumps says 'we don't need' the Defense Production Act as states struggle with supply shortages. Forbes. https://www.forbes.com/sites/mattperez/2020/03/26/ president-trump-says-we-dont-need-the-defense-production-act-as-states-struggle-with-supply-short ages/\#203237c45e55. Retrieved March 31, 2020.

Power, J., McGreevy, R., Wilson, J., \& Hutton, B. (2020, March 21, 2020). Coronavirus: Cases in Republic rise to 785 as government responses criticized. The Irish Times. https://www.irishtimes.com/ news/ireland/irish-news/coronavirus-cases-in-republic-rise-to-785-as-government-response-criticised -1.4209037. Retrieved March 31, 2020.

Racalossi de Moraes, G. (2020, March 2020) In practice, there are two pandemics: One for the well-off and one for the poor. Global Policy Opinion, $20 \mathrm{https} / / / w w w . g l o b a l p o l i c y j o u r n a l . c o m / b l o g / 20 / 03 / 2020 /$ practice-there-are-two-pandemics-one-well-and-one-poor. Retrieved March 31, 2020.

Rosenthal, U., Charles, M. T., \& 't Hart, P. T. (Eds.). (1989). Coping with crises: The management of disasters, riots, and terrorism. Springfield: Charles $\mathrm{C}$ Thomas Pub Limited.

Reuters. (2020, March 20, 2020). Brazil slashes growth, eyes healthcare collapse over coronavirus. New York Time. https://www.nytimes.com/reuters/2020/03/20/world/americas/20reuters-health-coronaviru s-brazil.html. Retrieved March 31, 2020.

Roy, E. A. (2020, March 9, 2020). Covid-19: New Zealand government accused of 'flat-footed' response. The Guardian. https://www.theguardian.com/world/2020/mar/10/covid-19-new-zealand-government -accused-of-flat-footed-response. Retrieved March 31, 2020.

Sanders, L. (2020, March 24, 2020). Most Americans don't trust President Trump for accurate COVID19 information says CBS/YouGov Poll. https://today.yougov.com/topics/politics/articles-repor ts/2020/03/24/who-americans-trust-covid. Retrieved March 31, 2020.

Shepherd, M. (2020, March 14, 2020). The COVID-19 coronavirus pandemic highlights the importance of scientific expertise. Forbes. https://www.forbes.com/sites/marshallshepherd/2020/03/14/covid-19-andthe-sudden-respect-of-science-expertise/\#2b2c792029b0. Retrieved March 31, 2020. 
Stern, E. (1997). Crisis and learning: A conceptual balance sheet. Journal of Contingencies and Crisis Management, 5(2), 69-86.

Stone, D. (2013). Taking emotion seriously: The promise of interpretive policy analysis. In Keynote speech to the 8th interpretive policy analysis conference. Vienna, July 4, 2013.

Stone, D. (2019). Making global policy. Cambridge University Press.

Stone, D., \& Ladi, S. (2015). Global public policy and transnational administration. Public Administration, 93(4), 839-855.

Torgerson, D. (2017). Policy sciences and democracy: A reexamination. Policy Sciences, 50(3), 339-350.

Varnum, P. (2020, March 16, 2020). Managing mental health during coronavirus-Experts around the world share insights. World Economic Forum. https://www.weforum.org/agenda/2020/03/covid19-coronaviru s-mental-health-expert-insights/. Retrieved March 31, 2020.

Voorberg, W. H., Bekkers, V. J., \& Tummers, L. G. (2015). A systematic review of co-creation and co-production: Embarking on the social innovation journey. Public Management Review, 17(9), 1333-1357.

Walker, G. T. P., et al. (2020) The Global Impact of COVID-19 and Strategies for Mitigation and Suppression. WHO Collaborating Centre for Infectious Disease Modelling, MRC Centre for Global Infectious Disease Analysis, Abdul Latif Jameel Institute for Disease and Emergency Analytics, Imperial College London.

Weible, C. M., \& Sabatier, P. A. (Eds.). (2017). Theories of the policy process. New York: Hachette.

Werner, E., Stein, J., \& DeBonis, M. (2020, March 18, 2020). Negotiations intensify on Capitol Hill over massive stimulus legislation as coronavirus fallout worsens. The Washington Post. https://www.washi ngtonpost.com/business/2020/03/18/trump-coronavirus-economic-plan/. March 16, 2020.

Woodruff, J. (2020, March 16, 2020). What lessons from the 2008 financial crisis can be applied to coronavirus economic fallout. PBS Newshour. https://www.pbs.org/newshour/show/what-lessons-from2008-financial-crisis-can-be-applied-to-coronavirus-economic-fallout. Retrieved March 31, 2020.

Yuan, L. (2020, January 22, 2020). China silences critics over deadly virus outbreak. New York Times. https ://www.nytimes.com/2020/01/22/health/virus-corona.html. Retrieved March 31, 2020.

Publisher's Note Springer Nature remains neutral with regard to jurisdictional claims in published maps and institutional affiliations. 